\title{
LA NORMA IDIOMÁTICA DEL ESPAÑOL: VISIÓN HISTÓRICA
}

\author{
Elena Méndez García de Paredes
}

\begin{abstract}
The concept of norm in Linguistics is ambiguous, and may lead to different derivations, since there are different ways in which it has been understood by scholars (traditional grammar, Hjelmslev, Coseriu...). The problem increases when we bear in mind that also in ordinary speech norm involves different meanings. Thus, one of the goals of this essay is, not only to clarify the meaning of this concept, but also to prove that this polysemy has interfered with the way in which linguists, grammarians or just curious people have understood the functioning and evolution of language. For this reason, a picture has been drawn of what in Spanish has been understood as norm in each period and since the Middle Age, and how this has interacted with the idiomatic evolution.
\end{abstract}

\section{PROBLEMAS CONCEPTUALES DEL TÉRMINO NORMA: COLISIÓN ENTRE LOS SIGNIFICADOS DE LA LENGUA Y LA METALENGUA}

Antes de abordar la historia de la norma idiomática del español, conviene hacer algunas precisiones sobre el término norma, pues, como bien señala L. F. Lara ${ }^{1}$, es uno de los más polisémicos y ambiguos de la ciencia lingüística, ya que en él se entrecruzan varios de los sentidos con que se emplea esta palabra en el español común, a la vez que ha recibido alguno más propiamente específico o técnico y desligado de los sentidos comunes (la norma de Hjelmslev, por ejemplo).

En el español común la palabra norma es polisémica, pues aunque aúna dos sentidos procedentes de orígenes distintos, la proximidad semántica y la dependencia mutua los convierte en dos acepciones de una misma entrada léxica. Una de las acepciones es patrimonial: a partir de un significado básico heredado del latín 'escuadra usada por los artífices para arreglar y ajustar los maderos, piedras y otras cosas ${ }^{\prime 2}$ se producen asociaciones más o menos figuradas que tienen como punto de partida 'la justeza con la que deben encajar las piezas'. De ahí, 'regla sobre la manera como se debe hacer o está establecido que se haga cierta cosa', fácilmente especializable en filosofía como término deontológico: 'regla con respecto a la que ajustar la conducta', es decir, canon, modelo, guía, ejemplo, y en derecho

\footnotetext{
'L. F. Lara: El concepto de norma en lingüística (México, Colegio de México, 1979), véase en especial el cap. I, "La palabra norma y sus sentidos", pág. 9 y ss.

${ }^{2}$ Vid. DRAE, norma. Semejante definición proporciona el Diccionario de María Moliner: 'Escuadra usada... para arreglar las piezas de modo que ajusten unas con otras'. Corominas-Pascual documentan por primera vez esta palabra en 1616.
} 
como precepto jurídico. Tales significados son los que mejor se avienen en la ciencia lingüística con norma de corrección y gramática normativa. Es decir, este significado de la lengua común es el que inspira el concepto tradicional de norma, 'modelo idiomático con respecto al cual debe ajustarse la conducta lingüística de los hablantes instruidos', equivalente, pues, a canon lingüístico o ejemplaridad idiomática.

El otro significado de norma en la lengua común es más moderno, pues deriva de un préstamo del francés, la palabra normal, no documentada para el español hasta el siglo XIX: 'lo que se tiene como corriente, ordinario y usual'. Esta acepción de la palabra norma en la lengua diaria es la que late en el tecnicismo lingüístico acuñado por E. Coseriu en 1952 en su conocido artículo "Sistema, norma y habla" ${ }^{3}$. Como bien se sabe, para este lingüista norma es un concepto relativo que sitúa la observación de los hechos lingüísticos entre la abstracción del sistema, que permite entender la lengua como una red de relaciones o estructura de elementos relacionados por oposición, y la concreción del habla. La norma de Coseriu reúne todas las ocurrencias que en el habla se manifiestan como regularidad, como hábito, como tradición idiomática. Todo hecho lingüístico que, pese a ser constante, es extrafuncional o asistemático. Se trata, pues, de una concepción del término bien distinta a la tradicional que subyace en gramática normativa o norma de prescripción; pero lo más importante es que, gracias a despojarse de cualquier implicación de prescriptivismo, se convierte en un concepto que recibe todos los honores dentro de una teoría lingüística que pretende ser científica:

Aclaramos, además, que no se trata de una norma en el sentido corriente, establecida o impuesta según criterios de corrección y de valoración subjetiva de lo expresado, sino de la norma que seguimos necesariamente por ser miembros de una comunidad lingüística, y no aquélla según la cual se reconoce que "hablamos bien" o de manera ejemplar, en la misma comunidad. Al comprobar la norma a la que nos referimos, se comprueba cómo se dice, y no se indica cómo se debe decir: los conceptos que, con respecto a ella, se oponen son normal y anormal, y no correcto e incorrecto. ${ }^{4}$

En efecto, es muy conocido el rechazo que en todas las corrientes lingüísticas de nuestro siglo ha tenido y sigue teniendo la prescripción gramatical. Así, desde los comienzos del estructuralismo se repite como fórmula de conjuro que la lingüística debe ser descriptiva; nunca, prescriptiva; ya que, como toda ciencia empírica, su sentido es ordenar los hechos y clasificar la multiplicidad aparentemente infinita de un modo científico, esto es, objetivo y real (que en los hechos lingüísticos está determinado por su valor o función). El lingüista, pues, debe alejarse de lo que es imposición convencional y normativa, basada por lo general en apreciaciones subjetivas y arbitrarias. El desarraigo de la prescripción de la teoría lingüística va acompañado del destierro de la valoración como criterio de enjuiciamiento de los hechos lingüísticos. En definitiva, para el lingüista no hay lenguas ni mejores ni peores, $\mathrm{y}$, puesto que una lengua histórica no lleva consigo un modo único de hablar "sino una

\footnotetext{
${ }^{3}$ Cfr. Teoría del lenguaje y lingüística general (Madrid: Gredos, 1973), 11-113.

${ }^{4}$ Art. cit., pág. 90 .
} 
'familia' histórica de modos de hablar afines e interdependientes" ${ }^{5}$, tampoco hay desde un punto de vista estrictamente teórico realizaciones concretas de una lengua más correctas que otras. La corrección ni es aplicable al sistema de la lengua, porque éste es por naturaleza correcto, ni tampoco en cierto modo se puede aplicar al habla, so pena de poner en tela de juicio la variación lingüística. Precisamente por estas razones la nomenclatura lingüística moderna dota de contenido específico, aunque no siempre unívoco ${ }^{6}$, al término norma, intentando desterrar cualquier atisbo de normatividad y prescripción.

En resumen, dentro del metalenguaje científico existen dos sentidos aparentemente opuestos del término norma (aparte, ya se ha dicho, queda el concepto de Hjelmslev): uno es 'lo normativo, lo canónico', el otro es 'lo habitual, lo acostumbrado'. El primero, de carácter prescriptivo, obsoleto ya por las connotaciones negativas que implica, pues norma se define como lo que debe ser. El segundo, el coseriano de norma, como hecho consuetudinario que se define como lo que es. Pero lo más significativo es que sus significados colisionan y se interfieren tanto en la lengua común ${ }^{7}$ como en el metalenguaje científico. Dicho de otro modo, parece evidente que en la lengua común existe cierta solidaridad semántica entre esos dos sentidos, y habría que preguntarse si esa solidaridad de la lengua común determina también una cierta interdependencia de los conceptos en la metalengua. Pues, como señala Luis Fernando Lara ${ }^{8}$, la proximidad semántica favorece el cruce y la dependencia mutua: las normas (preceptos) se pueden obtener por generalizaciones empíricas que se infieren de lo que es norma (costumbre). La costumbre se hace precepto cuando se codifica y una vez hecha norma, se adopta como elemento de juicio y establece el modelo de lo que debe ser (funciona como norma ejemplar). Y viceversa: la existencia de pautas que

${ }^{5}$ E. Coseriu: "Los conceptos de dialecto, nivel y estilo de lengua y el sentido propio de la dialectología", en LEA, III/1, (1981) 1-32, pág. 6.

\footnotetext{
${ }^{6}$ Recuérdese que en 1943 L. Hjelmslev en su artículo "Lengua y habla" introduce este concepto, dándole un sentido relativo, a medio camino entre el esquema de la lengua, cuya naturaleza es puramente formal y algebraica (conjunto de relaciones sintagmáticas y paradigmáticas previas a la realización material o normal de la lengua), y la concreción del acto, hecho uso. En la norma de Hjelmslev, los elementos de la lengua funcionan también a base de relaciones opositivas (como en el esquema), sólo que, al sustentarse en la realización material de la lengua, la oposición puede hacerse ya a partir de su cualidad positiva (su rasgo funcional o distintivo). Cfr. Ensayos lingüísticos (Madrid, Gredos, 1972), 90-115. Tal concepción del término norma está muy alejado de los planteamientos que se pretenden en este artículo y no volverá a plantearse en la páginas que siguen.

${ }^{7}$ Que esta cuasi-homonimia pueda producir efectos perturbadores que dificulten la distinción es claro en la lengua común, ello se pone de manifiesto en expresiones del tipo: tener algo como norma, equivalente tanto a 'tener algo como costumbre' como a 'tenerlo como obligación'. Véase también la alternancia: es norma (costumbre, hábito) de la casa / es la norma (el deber ser al que hay que acogerse) de la casa, en donde la ausencia vs. presencia del artículo es determinante en la diferenciación significativa. De hecho, María Moliner en su Diccionario de uso del español ofrece dentro de la misma acepción del vocablo (la segunda) una serie de palabras afines acostumbrado. corriente, natural, ordinario, regular; claramente separadas de criterio, ejemplo, guía, instrucción, precepto, principio... (pero incluidas también dentro de esa acepción). Es decir, la cuasi-homonimia de norma, en la que confluyen sentidos procedentes de dos canales de transmisión (norma, latinismo, y normal, galicismo), se manifiesta como una adjunción de significados por las implicaciones inferidas por el uso de la palabra norma en su sentido primario, esto es, se manifiesta como una polisemia.

${ }^{8}$ El concepto de norma..., cap. I. También habla de estas cuestiones el artículo de Alain Rey:"Usages, jugements et prescriptions linguistiques" en La norma; Langue Française (1972), 5-28 (vid. sobre todo págs. 4-8).
} 
rigen un comportamiento (normas prescriptivas) se manifiesta en el ser las cosas, en la regularidad, en el hábito (normas consuetudinarias). Es decir, los dos conceptos de norma, el tradicional y el coseriano, no están tan alejados como en principio se pretendía. El propio Coseriu habla de que es la norma la que se impone al individuo, no el sistema. De hecho él mismo, aun sin querer ver la interdependencia de una y otra normas, lo pone de manifiesto:

El hecho de que las dos normas puedan coincidir no nos interesa aquí; cabe, sin embargo, señalar que muchas veces no coinciden, dado que la "norma normal" se adelanta a la "norma correcta", es siempre anterior a su propia codificación."

Y también lo señala A. Rosenblat, en respuesta a la concepción de norma de Coseriu:

De todos modos, esa norma codificable ¿no es precisamente, en cada esfera o nivel de lenguaje, el fundamento de toda normatividad? ¿No es toda norma una especie de modelo ideal? Nos parece, pues, evidente, por todos los caminos, que el estudio de las normas de ejemplaridad o de corrección o de aceptabilidad social es insoslayable en el vasto y complejo campo de nuestro quehacer lingüístico, teórico y aplicado. ${ }^{10}$

Todavía hoy sigue formulándose la pregunta de si una gramática debe ser la simple descripción de una lengua (en cuyo caso conviene plantearse también qué tipo de descripción hacer), o una selección normativa dentro de un uso ${ }^{11}$. De hecho, como bien se sabe, por muy exhaustivo que se pretenda el estudio de una lengua, éste es por propia naturaleza selectivo, dado que todo estudio científico del lenguaje implica una reducción inicial del objeto de estudio $^{12}$. El lingüista al describir la gramática de una lengua opera, por lo generai, de un modo inductivo: abstrae el funcionamiento del sistema de la lengua a partir de un corpus de datos lo más rico posible. Pero el uso de los hablantes de una lengua es en sí mismo inabarcable ${ }^{13}$, así que la reducción empieza por el usuario de la lengua, el hablanteoyente ideal de algunas escuelas, que al final acaba siendo el mismo estudioso, pues la introspección se convierte en método de análisis no sólo válido, sino en ciertos casos exclusivo. Si tenemos bien presente esto, habrá que admitir que la descripción del gramático no es la lengua ni debe confundirse con ella. Pese a todo, ésta es una ficción que persiste en el

\footnotetext{
${ }^{9}$ Art. cit., pág. 90.

${ }^{10} \mathrm{Cfr}$. "El criterio de corrección en lingüística: unidad o pluralidad de normas en el castellano de España y América" (1967), en Estudios sobre el español de América, III (Caracas: Monte Ávila Editores, 1984), 311-337, vid. pág. 337.

${ }^{11}$ Así lo hace F. Rodríguez Adrados: "El idioma español y su valor", BRAE, LXXXIII, cuad. CCLIX (1993), 303327.

${ }^{12} \mathrm{Y}$ estos es mucho más acusado en lingüística, pues el inmanentismo postulado por Saussure obliga a olvidar los aspectos psicológicos, sociales, históricos, contextuales, como elementos explicativos del funcionamiento de la lengua.

${ }^{13}$ Entre nosotros, quizá sea la Gramática del S. Fernández Ramírez la que cuenta con un corpus más vasto y, sin embargo, el propio autor era consciente de sus limitaciones: "Desgraciadamente, mi capacidad para la recogida de materiales ha tenido un límite y solo en porción mínima puedo aducir hay autoridades de escritores americanos". "Prólogo a la edición de 1951", Gramática española (1. Prolegómenos) (vol. preparado por J. Polo) (Madrid, Arco/Libros, 1985), 308.
} 
hablante ingenuo que hace de la descripción hecha por el gramático norma (en el sentido de canon o modelo)de su actuación ${ }^{14}$. Y de rechazo, califica y valora negativamente toda variación en el uso que no esté acogida en la descripción gramatical. El problema, por tanto, no es en primera instancia, como podría suponerse, de selección normativa, sino de selección de un uso para proceder a su descripción. Y, hasta el momento, la mayoría de nuestros gramáticos ha trabajado con un corpus de ejemplos de la lengua literaria escrita ${ }^{15}$. Basten como ejemplo los siguientes textos extraídos de varios prólogos:

El material que he utilizado es exclusivamente literario. Pocas veces he manejado testimonios orales. Este hecho hará pensar, probablemente que me alejo de la fuente viva del decir y que mi Gramática toma una orientación filológica más que lingüística. Es posible que así sea. (...). Rehuyo, por otra parte, la anotación de los hechos más aberrantes de la norma común, especialmente en la fonética y en la morfología, (...)Pero no debe perderse de vista que mi objetivo es el español común, el español cuidado que hablan las gentes cultas y universitarias de Madrid. Y entre ese español hablado y literario no existe, sobre todo en nuestros días, una distancia considerable. Las diferencias son más de léxico que de gramática. ( $\mathrm{S}$. Fernández Ramírez: Gramática española (1. Prolegómenos), Madrid, Arco/Libros, 1985, vid. "Prólogo a la edición de 1951", en pág. 307-308).

En todo caso se ha apoyado la descripción en la autoridad de escritores dominantemente peninsulares, que escribieron a finales del siglo pasado o en el siglo XX hasta nuestros días. (J. Alcina-J. M. Blecua: Gramática española, Barcelona, Ariel, 1975, pág. 11.)

Mi propósito consistía en exponer los rasgos de la gramática del español que se descubren en los actos orales y escritos de los usuarios de la lengua en este siglo XX. Hoy día concurren normas cultas diversas en los vastos territorios donde se practica el español como lengua materna. Ya no es posible sostener, como un siglo atrás hacía Leopoldo Alas, que los peninsulares somos los amos del idioma... Se comprende y hasta se justifica que cada uno encuentre más eficaz y precisa la norma lingüística a cuya sombra ha nacido y se ha formado; pero ello no implica rechazo o condena a otras normas tan respetables como la propia. La Academia, con mutaciones varias a lo largo de sus casi tres siglos de vida, ha defendido criterios de corrección basados en el uso de los varones más doctos, según decía Nebrija. El redactor ha procurado la imparcialidad en los casos de conflictos normativos, si bien se reflejan a veces sus preferencias personales. (E. Alarcos Llorach: "Prólogo" a su Gramática de la lengua española (Madrid, Espasa-Calpe, 1994) pág. 20.)

\footnotetext{
${ }^{14}$ En este sentido hay que entender la postura de J. J. Montes Giraldo cuando dice: "este pretendido universalismo de la lengua literaria culta ha marcado su huella en la gramática tradicional y en los estudios lingüísticos y filológicos. Así, de la gramática de las 'lenguas' clásicas, fundadas evidentemente sobre el dialecto literario, a la gramática de las lenguas modernas y aun a la lingüística con las leyes fonéticas sin excepción, el estructuralismo con su concepción del sistema rígido y único y el transformacionalismo con su confianza en el hablante ideal, se ha mantenido la ficción de que la descripción de una parte de un sistema lingüístico, así sea una parte muy importante, es una descripción válida del conjunto total". Vid. "Lengua, dialecto y norma", Thesaurus XXXV (1980) $237-$ 257, pág. 240.

${ }^{15}$ Este problema no se plantea en las gramáticas cuya descripción se basa en ejemplos inventados, pero como acertadamente señala S. Fernández Ramírez: "La lengua sirve a todas las necesidades comunicativas, expresivas y apelativas del hombre, menos a las construcciones artificiales de los gramáticos. Es muy conveniente advertirlo." Cfr. "Prólogo a la edición de 1951", Gramática española (1. Prolegómenos) (Madrid, Arco/Libros, 1985), 306.
} 
Por eso, como decía E. Alarcos Llorach, lingüista tolerante y partidario del laissez-faire y "dejar a las lenguas en paz", nada sospechoso, por tanto de dogmatismo normativo: "Toda gramática empieza o termina por ser normativa" ${ }^{16}$. Esto es, el mismo hecho de seleccionar ciertos usos - "los de los varones más doctos", según quería Nebrija- como los más adecuados para basar en ellos la gramática de una lengua, los convierte, aun sin querer, en la gramática de esa lengua, en la norma ${ }^{17}$. El uso descrito se hace norma y sirve de pauta para normalizar el comportamiento lingüístico de los hablantes que hacen suya esa gramática de su lengua. Se trata, por así decir, de un camino de ida y vuelta, de un fenómeno retroactivo: del uso a la gramática y de la gramática al uso. El uso debe ser fundamento de la gramática, pero al mismo tiempo la gramática actúa como fundamento del uso. Parece, pues, que descripción y prescripción normativa no son conceptos antagónicos sino graduales, pues toda gramática descriptiva determina una norma de ejemplaridad implicada en la selección previa de los datos extraídos de uno o varios usos particulares ${ }^{18}$.

Como se ve norma 'costumbre' y norma 'uso o modelo codificado que los hablantes toman como guía o pauta para ajustar sus producciones lingüísticas', también en la práctica lingüística son solidarias. Y sin embargo, se da la paradoja de que uno de los conceptos es plenamente aceptado dentro de la teoría lingüística mientras que el otro se repudia por su presunto acientifismo. Dicho de otro modo: existe una norma lingüística que es digna de consideración por la Lingüística porque se presume objetiva y, por tanto, intralingüística; y otra norma, tenida como subjetiva y extralingüística, pero que se deriva de la codificación de la anterior. Habría, pues, que preguntarse ${ }^{19}$, si hay manera de conjugar dentro de la teo-

\footnotetext{
16 "Se ha procurado que la actitud normativa no borrara la descripción de los hechos y que esta no ocultase, desarrollada en demasía, la claridad de la norma y el propósito didáctico", Cfr. E. Alarcos: Ibidem., pág. 20. Algo semejante se puede leer en la entrada Norma lingüística en el Diccionario de lingüística de T. Lewandowski: "Al escribir una gramática no es posible prescindir de la n. 1., que corresponde a los intereses existenciales de la actividad social, que se rige por normas. La "estructura" (gramática o sintaxis) de la lengua parece menos flexible que el vocabulario y la estilística". Pág. 243.

${ }^{17}$ Esto es algo que resulta hoy evidente. Durante mucho tiempo han sido los textos escritos, por otra parte más fáciles de fijar, anotar y analizar, los que han servido de base para la descripción de las lenguas. Luego esas mismas descripciones se trasplantaban sin más a los usos orales de la lengua, sin tener en cuenta que los usos válidos en lo escrito, no lo eran del todo en lo oral. Sin pensar que el coloquio, incluso en el nivel culto, tal y como intentan demostrar las investigaciones que en este campo se están realizando en la actualidad, tiene su propia gramática y que ésta no se corresponde punto por punto con la de los textos escritos. Por ello, no creo que sea totalmente ajustada la idea de S. Fernández Ramírez expuesta en el texto arriba citado: "Y entre ese español hablado y literario no existe, sobre todo en nuestros días, una distancia considerable. Las diferencias son más de léxico que de gramática".

${ }^{18}$ Hay descripción en tanto en cuanto el gramático se sirve de los datos para analizar y explicar el funcionamiento interno de la lengua. Por contra, si la autoridad de los datos sólo sirve como criterio para "la exposición de los hechos a un seco repertorio de usos correctos e incorrectos, sin dar ninguna explicación, como el viejísimo Appendix Probi", ya no es gramática. Cfr. E. Alarcos Llorach; Gramática..., pág. 20.

${ }^{19}$ Acaban de citarse las palabras de Rosenblat al respecto, pero también pueden citarse los planteamientos de ciertos lingüistas de la Escuela de Praga en relación con una normalización y normativización del checo (cfr. A. Gallardo: "Hacia una teoría del idioma estándar" en RLA, 16, 1978, págs. 85-119. Y A. Torrejón: Andrés Bello y la lengua culta. La estandarización del castellano en América en el siglo XIX, Society of Spanish anda SpanishAmerican Studies, 1993), y la obra, ya citada, de L. F. Lara, El concepto de norma en lingüística.
} 
ría lingüística ambos conceptos, dándole a cada uno de ellos el lugar que les corresponda. Pero, para ello es necesario saber integrar en la descripción gramatical el fenómeno de la variación de la lengua estándar y los condicionamientos pragmáticos en que se produce, pues sólo desde estos planteamientos se despojaría a la norma prescriptiva de sus connotaciones negativas, ya que los rasgos idiomáticos variables se evaluarían no con respecto a un ideal monolítico y unitario de lengua, propio de lo que J. J. Montes Giraldo llama "universalismo lingüístico" (porque concibe uno de los modos de ser la lengua con la lengua toda ${ }^{20}$ ), sino con respecto a la adecuación estilística de tales variantes en función de la situación comunicativa. En este sentido tiene razón cuando dice:

En cuanto a partir de normas consuetudinarias de un dialecto dado en un lugar y época dados se extrae una norma que se trata de imponer a todo el complejo lingüístico como leyes válidas de la 'lengua', no de un dialecto particular. No importa que este dialecto no sea estrictamente el de un lugar concreto, sino una mezcla especial de la norma consuetudinaria real de un dialecto territorial con el dialecto literario basado en aquél. (...) Esta concepción de la normatividad en la lengua hace crisis y comienza a imponerse una normatividad que ya no es la exclusiva del dialecto otrora central y dominante. ${ }^{21}$

Es cierto que durante mucho tiempo el problema de la unidad de la lengua española ha estado sustentada en la idea de un modelo único de lengua, de forma que cualquier realización que se apartara de este modelo se veía como un indicio de fragmentación. Sin embargo, hoy parece claro que bajo esta concepción universalista y monolítica, que convierte uno

\footnotetext{
${ }^{20}$ A estas alturas de la ciencia lingüística resulta descabellado sustentar el criterio de corrección idiomática en una idea monolítica de la lengua, pues si en algo ha fallado el criterio de corrección tradicional ha sido en la confusión de planos de aplicación, lo que le ha valido las merecidas calificaciones de injusto y discutible, ya que aplicaba un mismo patrón regulador a cualquier circunstancia de habla. Pongo como ejemplo de esta tendencia la obra de A. Llorente Maldonado de Guevara, La norma lingüística del español actual y sus transgresiones (I.U.C.E, Universidad de Salamanca, 1991), porque creo es un claro ejemplo de ello. En efecto, este autor, tras hacer una especie de declaración de principios en donde habla de que el concepto de norma es controvertido porque es convencional, arbitrario y difícil de fijar, aunque para ello suelen tenerse en cuenta la tradición literaria, el buen gusto, la conciencia y el sentido lingüísticos de los hablantes cultos, y el consejo de los gramáticos prestigiosos, declara que la norma del español la determinan: la Gramática y el Diccionario de la Academia, Navarro Tomás, en lo que respecta a la pronunciación, y gramáticos eminentes (Bello, Cuervo, Lapesa, Seco, Lázaro, Alarcos, etc.). Con estos parámetros, aplicables sin excepción a cualquier situación del hablar, además de reconocer como transgresiones los típicos casos de vulgarismos y semicultismos, incluye también lo que llama "transgresiones regionales" en las que se le plantea el problema de si conviene tenerlas como vulgarismos o simplemente como regionalismos: si la transgresión es propia de la gente humilde, iletrada es vulgar; pero si no es patrimonio exclusivo de tales capas sociales, sería una transgresión, pero no un vulgarismo. Cfr. op. cit., pág. 11-15. Así, p.e., en la pág. 26 dice este autor: "Una incorrección característica tanto del andaluz occidental como del español de Canarias y del español de América es la pérdida de la oposición VOSOTROS/USTEDES a favor de USTEDES, perdiéndose así la oportunidad de distinguir, cuando nos dirigimos a varias personas, entre el tratamiento de confianza y el tratamiento de respeto", y añade: "En el español de América y en el español de Canarias USTEDES se combina con la forma verbal correspondiente a $3^{a}$ persona (...) con lo cual a la incorrección de base no se añade una nueva incorrección sintáctica, puesto que hay concordancia, se respeta la concordancia". El mismo término transgresión a la norma, aplicado desde las referencias anteriormente citadas, da a corrección una resonancia de carácter moral totalmente inapropiada dentro de una lingüística científica. Pero lo más importante de todo es que identifica correcto y ejemplar dentro de la más pura tradición casticista y purista del idioma, por ello su observación queda fuera de toda norma objetiva, esto es, fuera de toda norma de uso y costumbre.
}

${ }^{21}$ (J. J. Montes Giraldo: "Lengua, dialecto y norma” en Thesaurus XXXV (1980), 237-257; vid. págs. 252-253. 
de los modos de ser una lengua en la lengua toda, no tiene cabida un concepto de norma ejemplar defendible desde el punto de vista científico de la teoría lingüística. El problema de la corrección idiomática no puede convertirse en un academicismo ciego, en una adecuación fiel y sistemática a las gramáticas, diccionarios y otros tratados ya existentes (basados por lo general en la lengua escrita y más aún, en la lengua escrita literaria), porque es un problema muy complejo y es precisamente en toda su complejidad como hay que abordarlo, es decir, teniendo en cuenta los distintos niveles lingüísticos y las distintas circunstancias del hablar individual, que no hace más que acomodarse a las pautas sociales. Como ya puso de manifiesto $O$. Jespersen ${ }^{22}$ en cualquier comunidad por pequeña que sea existe un ideal expresivo que es modelo para las realizaciones concretas de sus miembros, por consiguiente existe un criterio interno de corrección que determina que el hablante pueda elegir sus usos lingüísticos en función de la situación comunicativa. Esto ha llevado a muchos lingüistas (entre ellos al propio Jespersen) a plantearse ¿qué debe entenderse por corrección?, ¿qué papel le corresponde a lo usual en la formación de los modelos de corrección? y ¿cómo actúan las normas de corrección en la conciencia del hablante? ${ }^{23}$

\section{VISIÓN HISTÓRICA DE LA NORMA DEL ESPAÑOL: UN REPASO A LA HIS- TORIA DE LAS IDEAS LINGÜÍSTICAS Y DE LA CODIFICACIÓN GRAMATI- CAL}

Por todo lo apuntado, creo que para acercarse históricamente a la norma del español (cualquiera que sea su consideración: descriptiva o prescriptiva) el historiador de la lengua debe tener en cuenta ciertos hechos que se condicionan e, incluso, se interfieren. Éstos, por un lado, tienen que ver con las ideas lingüísticas imperantes en cada momento, pues si, como hemos visto, los preceptos se pueden obtener por generalización de lo que es uso o costumbre idiomática, y viceversa, si los usos idiomáticos pueden hacerse preceptos cuando se codifican, merece la pena indagar sobre todo aquello que tiene que ver con la codificación de la lengua. A saber: 1) razones argüidas por las que se considera necesaria la codificación de una lengua, 2) selección de un determinado uso de entre los muchos posibles y 3) su codificación gramatical. En este sentido, es presumible pensar que, conforme han ido cambiando las concepciones lingüísticas, éstas forzosamente han debido reflejarse en la selección y fijación de un uso, y que, por tanto, la historia de las normas idiomáticas (es decir, de la sustitución de unos modelos de ejemplaridad por otros) está influida o mediatizada por las concepciones científicas de los gramáticos. Esto, en el caso del español se confirma, pues ha llegado, incluso, a condicionar el nombre que se le ha dado a la lengua:

\footnotetext{
${ }^{22}$ Cfr. "Energetik der Sprache", de 1914; cit. por L. F. Lara, El concepto de norma en lingüística, pág. 87, nota 4. Precisamente fue Jespersen el primer lingüista que desde el punto de vista de la teoría lingüística se preguntaba si el lingüista podía abordar el estudio de los aspectos normativos y sus consecuencias para la sociedad: "Es completamente cierto que, tanto en regiones civilizadas como en lugares incivilizdos, hay una especie de opinión pública -que en última instancia es igual en una y otra circunstancia cultural- que influye sobre el uso de la lengua". Vid. L. F. Lara, pág. 87.

${ }^{23}$ Cfr. L. F. Lara, op. cit, capítulos 4 y 5.
} 
castellano y español han sido, y son todavía hoy, términos que contienden con mayor o menor virulencia en la denominación de nuestra lengua.

Ahora bien, por otro lado, no podemos llevar a cabo este estudio sin considerar cómo han ido calando, como por un efecto de ósmosis, esas ideas lingüísticas en el común de los hablantes, condicionando con ello su percepción más o menos ingenua de la norma de nuestra lengua. Pues, como se sabe, la historia de las normas idiomáticas no es más que la historia de las creencias, de los juicios y prejuicios sobre los que se asientan las diversas comunidades de habla que constituyen una lengua histórica, y que muchas veces condicionan y pueden llegar a distorsionar la visión de lingüistas y gramáticos. Dicho de otra manera, un estudio sobre la historia de la norma del español debe saber conjugar dos tipos de creencias sobre la lengua: las de los hablantes y las de los gramáticos.

Puede decirse que las ideas que determinan la concepción de la lengua por los hablantes no ha cambiado mucho a lo largo de los siglos, porque se asienta en la preocupación, de sobra conocida, que siente el hablante medio con respecto al juicio o valoración que ha de darse a su forma de hablar, manifestándose así la presión que ejerce la comunidad hablante en el funcionamiento de las lenguas, que potencia unos usos como aceptables o buenos en detrimento de otros que se rechazan por carecer de prestigio social. El hablante tiene conciencia de que todas las formas de hablar no son iguales, y cree que hay un canon, un modelo, cuya codificación (en gramáticas y diccionarios) da instrucciones para seguirlo. Es decir, la conciencia lingüística de los hablantes está mediatizada por los diferentes significados de norma en la lengua común (de ahí la creencia ingenua de que todo lo que no aparece en el diccionario o no debe existir o no debe estar porque es anómalo e incorrecto, y, de rechazo, la tendencia a la hipercorrección, sobre todo en hablantes instruidos ${ }^{24}$ ). Por esta razón suelen ser habituales dos cuestiones que, aunque para el gramático sean irrelevantes, cobran absoluta pertinencia dentro de las actitudes que mantienen los hablantes respecto de la lengua: qué forma de hablar es mejor y dónde se habla el mejor español ${ }^{25}$, pues en ellas

\footnotetext{
${ }^{24}$ Así por ejemplo, una perspectiva muy interesante dentro de la investigación gramatical sería analizar las disposiciones normativas de la Academia (bien las disposiciones de apoyo a la norma, bien las conformadoras de norma) y su incidencia en la lengua literaria y en la lengua culta en general (por ejemplo, la tolerancia del laísmo sustentado en el principio de claridad hizo que escritores andaluces, nc laístas por tanto, adoptaran el laísmo en sus obras, tal es el caso de J. Valera o Estébanez Calderón; o la fijación morfológica de placer, yacer y erguir e, incluso, la oposición deber de + infinitivo / deber + infinitivo. Cfr. la propuesta de D. Fries, La Real Academia ante el uso de la lengua (1713-1973) (Madrid, SGEL, 1989) págs. 149-151.), esto es, examinar los resultados alcanzados dentro de la historia de la lengua y su actuación como catalizador del cambio lingüístico. Es un hecho el éxito alcanzado con la normalización ortográfica, pero muy poco se sabe de la fijeza normativa alcanzada en otros ámbitos gracias a la labor académica.

${ }^{25}$ Así, en España suele ser bastante general la idea de que los hispanoamericanos cuidan más el idioma, incluso muchas veces se ha puesto de paradigma el habla de Colombia como prototipo del mejor español. De Alejo Carpentier son las siguiente palabras citadas por A. Rosenblat ("Lengua literaria y lengua popular en América" en Estudios sobre el español de América, III (Caracas, Monte Ávila Editores, 1984) págs. 261-310, pág. 310): "aunque la afirmación puede parecer osada, el latinoamericano habla, por lo general, un castellano mejor que el que se habla en España". Esto contrasta con las apreciaciones de J. L. Borges: "He viajado por Cataluña, por Alicante, por Andalucía, por Castilla; he vivido un par de años en Valldemosa y uno en Madrid; tengo gratísismos recuerdos de esos lugares; no he observado jamás que los español hablaran mejor que nosotros..." (ibidem., pág. 310). Entre los andaluces suelen estar bastante extendidas las opiniones de Torrente Ballester, difundidas en
} 
suele descansar ese ideal de lengua que subyace en la conciencia de los hablantes. Parece como si al circunscribir la multiforme realidad lingüística a un canon determinado tal ideal fuera más asible y fácil de alcanzar, pues -como señala Havránek- no se debe olvidar que "cada miembro de una sociedad dirige su hablar según su sociedad, según su norma lingüística, la cual, en consecuencia, se le impone directa e indirectamente bajo la presión de la convivencia social ${ }^{26}$.

No se puede decir que la sociedad, o al menos una parte determinante de la sociedad española (que es precisamente la sociedad culta), tenga conciencia de un ideal de lengua hasta el humanismo ${ }^{27}$, con el ensalzamiento de las lenguas vulgares hasta el punto de poder parangonarse con el latín (hasta entonces el ideal de lengua estaba en el latín) y de ser dignas de "ser reducidas a arte". En esa conciencia colectiva el ideal de lengua es sobre todo geográfico, pero entreverado con lo social que late en el ideal cortesano. Es el habla de Toledo la que tiene el privilegio de ser modelo del buen hablar. Apenas si aparecen datos lingüísticos concretos que, por contraposición al habla de otras zonas, permitan hacernos saber en qué se sustentaba tal ideal (más bien lo contrario, pues se la acusaba de estar fuertemente arabizada). Sin embargo, como ya ponen de manifiesto M. Menéndez Pelayo, R. Menéndez Pidal y A. Alonso, según parece, las excelencias del habla toledana (calificada de "pulida y copiosa" o de "castellano claro y limado") casaban muy bien con el ideal cortesano del Renacimiento $^{28}$. La primera documentación es de 1530 y se debe a Lucio Marineo Sículo, que como extranjero en la corte de España es sensible al sentir generalizado de sus gentes:

La habla que agora los españoles en lugar de romana llaman romance [...] es latina corrompida, y adonde mas polida y copiosamente se habla es en las principales cibdades del Andaluzía y mucho más en Castilla, principalmente en el Reyno de Toledo, aunque es toda muy prima desde la cibdad de Sevilla hasta Burgos y Çaragoça de Aragón ${ }^{29}$,

entrevistas periodísticas hechas por medios de comunicación locales, de que en Andalucía se habla un español riquísimo, que es donde mejor se habla en la actualidad.

${ }^{26}$ Citado por L. F. Lara: El concepto..., pág. 92.

${ }^{27}$ Con la excepción quizá de un cierto ideal de lengua encarnado aparentemente por Alfonso el Sabio, el llamado "castellano derecho". Sí había, en cambio, un ideal estilístico de claridad y precisión que va desde "el mucho hablar hace envilecer las palabras" del propio Alfonso X, hasta la formulación de D. Juan Manuel: decir las cosas con el menor número de palabras posibles.

${ }^{28}$ Tal como decía F. López de Villalobos, más defensor del ideal artístico y cultural que del geográfico y social: "Aunque allí presumen (en Toledo) de que su habla es el dechado de Castilla, y tienen razón de pensallo así, por la gran nobleza de caballeros y damas que allí viven". Citado por A. Alonso en Castellano, español, idioma nacional. Historia espiritual de tres nombres, $5^{2}$ edic., Buenos Aires, Losada, 1979, pág. 62.

${ }^{29}$ Citado por F. González Ollé: "Aspectos de la norma lingüística toledana" en Actas del I Congreso de Historia de la Lengua Española (Cáceres, 30 de marzo al 4 de abril de 1987), (Madrid, Arco/Libros, 1988) págs. 859-871; pág. 860. En este artículo y en otros posteriores el autor busca el fundamento real de tales actitudes hacia la norma toledana: cfr. "Nuevos datos sobre la primacía lingüística toledana", RFE, LXVII (1987) págs. 123-126; "Un informe de 1576 sobre el habla de Toledo y su aplicación al modelo idiomático", Homenaje a E. Asensio (Madrid, Gredos, 1988) págs. 215-223; y "Un caso de aplicación (1560) del privilegio lingüístico alfonsino" Cahiers de linguistique hispanique médievale, 20, (1995) págs. 269-343. 
sentir que, según los testimonios documentales aportados por F. González-Ollé (véanse los artículos citados en la nota anterior), se repite durante los siglos XVI y XVII y queda conciencia todavía de ese ideal en los siglos XVIII, XIX y aún a principios del XX (no obstante, en estos siglos el ideal geográfico está en Castilla la Vieja). Una frase atribuida por M. Pidal a la reina Isabel la Católica: "Nunca me hallo necia sino quando estoy en Toledo" ${ }^{30}$, y un refrán popular recogido por Rodríguez Marín: "Lengua castellana, en boca toledana", pueden bastar para ejemplificar las actitudes pasadas, en las que -como señala A. Alonsono se oponían las hablas castellanas a las de Toledo como las de una región a otra, "sino más bien la instancia supra-regional al particularismo regional. Por eso no hubo nunca peligro de que se suplantase 'castellano' por 'toledano'”31. Sin embargo, las razones de por qué Toledo se erige como ideal lingüístico no parecen estar muy claras ${ }^{32}$. Lo que sí es cierto es que en la creencia popular operaba una supuesta disposición del rey Alfonso X que otorgaba a los toledanos, en función de su origen, el privilegio de arbitrar una solución a interpretaciones contrapuestas de textos legales ${ }^{33}$. Aunque resulta inexplicable que antes de esta época no haya noticias de tal privilegio ni tampoco testimonios fehacientes de que existiese tal disposición, el hecho es que era un tópico, un lugar común para la sociedad

\footnotetext{
${ }^{30}$ M. Pidal: La lengua de Cristóbal Colón, $5^{\text {a }}$ edic., (Madrid, Espasa-Calpe, 1968) pág. 52.

${ }^{31}$ A. Alonso: Castellano, español, idioma nacional. Historia espiritual de tres nombres, $5^{2}$ edic., (Buenos Aires, Losada, 1979) pág. 62.
}

${ }^{32}$ De hecho, el prestigio reconocido de la ejemplaridad toledana, compañera de todo aquel que se preciase de ser buen cortesano, de poco sirvió para que se perpetuaran sus modos lingüísticos: la aspiración suave heredera de la F- inicial latina, representada en los textos con la grafía h, se perdió (aunque perdurara por razones etimológicas la grafía), lo mismo que la distinción bilabial / labicdental concomitante del rasgo oclusivo / fricativo con que se articulaban b y v, según su distinta procedencia etimológica, como también se perdieron las distinciones entre sordas y sonoras en las tres parejas de sibilantes: dentales, ç, c / z; alveolares, ss / s y prepalatales x/ j,g e, i, i. Rasgos todos ellos que suponemos eran propios de la norma toledana, aunque tal atribución no es absolutamente segura. De hecho, el cambio hacia la pronunciación moderna y los reajustes fonológicos que se producen entre los siglos XVI y XVII se vienen explicando como un cambio de norma que coincide aproximadamente con el traslado de la corte de Toledo a Madrid por Felipe II en 1560. R. Lapesa sugirió la hipótesis de que la aceptación por parte del habla de la corte de la pronunciación norteña propia de castellanos viejos llevara implícito un deseo por despojarse de los hábitos toledanos para no ser tildados de conversos, pues es de todos conocido el peso específico que tuvo la judería toledana. Cfr. Ponencia presentada en el Simposio Internacional de Investigadores de la Lengua Española (Sevilla, del 9 al 13 de diciembre de 1991).

${ }^{33}$ Esta circunstancia ha sido bien estudiada por J. R. Lodares: "Alfonso el Sabio y la lengua de Toledo (un motivo político-jurídico en la promoción del castellano medieval)", RFE, LXXV, 1-2 (1995) págs. 35-56. Al parecer las alabanzas que convierten el habla toledana en "lengua pulida y copiosa", "castellano claro y limado", "corte de nuestro lenguaje y lo más elegante de siempre" no es más que la extensión de un tópico que tiene una lejana y distorsionada base histórico-jurídica: la unificación jurídica comenzada en época de Fernando III y continuada por su hijo Alfonso X sobre la base del Fuero de Toledo a cuya imagen se compusieron los fueros de las nuevas ciudades conquistadas. Esto supuso que la cancillería toledana y el propio rey resolvían las dudas procesales que se les consultaban, pero no sólo las de ese tipo sino también las lingüísticas, pues la unificación jurídica implicó también la modernización y castellanización de la lengua cancilleresca, por lo que presumiblemente también se suscitarían dudas terminológicas básicas para la aplicación de las leyes, con lo cual se extendió "la idea de que Toledo decide", convirtiendo en foco de prestigio lingüístico el habla de la ciudad. La idea que corría de boca en boca de que el rey Sabio había otorgado a Toledo el privilegio de dirimir en cuestiones legales y lingüística, no es más que una distorsión que tiene su origen en una decisión práctica y política: que se entiendan bien las leyes, y para ello es necesaria la incorporación del castellano a las tareas jurídicas y la unificación de los fueros otorgados. 
humanista, y de esa supuesta ley se hacen eco muchos eruditos y escritores de esa época en adelante:

Dicen que una ley dispone / que si acaso se levanta / sobre un vocablo porfía / de la lengua castellana, lo juzgue el que es de Toledo. (Lope de Vega: Amar sin saber a quién, cit. por F. González-Ollé, pág. 865$)^{34}$.

En cuanto a los gramáticos, no podemos olvidar que sus, creencias y consideraciones sobre la lengua marcaron durante siglos la norma del español y, consecuentemente, determinaron también la visión ingenua de los hablantes. Así, es un hecho que nuestra tradición gramatical nació con fines normativos, como un intento de paliar la evolución de las lenguas, pues la idea imperante era la de que las lenguas se corrompían por el mal uso que de ella hacían sus hablantes, especialmente los tenidos por incultos, rústicos y vulgares ${ }^{35}$, por esa razón algunas de nuestras mejores gramáticas son a la vez descriptivas y normativas. La herencia grecolatina plasmada en el ars recte loquendi de Quintiliano está presente en toda nuestra tradición gramatical humanística que concibe la Gramática como un arte o como una ciencia prescriptiva que "enseña a hablar y escribir rectamente":

Los que bolvieron de griego en latín este nombre, gramática, llamaronla arte de letras, $\tau$ a los professores $\tau$ maestros della dixeron grammaticos, que en nuestra lengua podemos dezir letrados. Ésta, según Quintiliano, en dos partes se gasta: la primera los griegos llamaron methódica, que nos otros podemos bolver en doctrinal, por que contiene los preceptos $\tau$ reglas del arte; la cual, aun que sea cogida del uso de aquellos que tienen autoridad para lo poder hazer, defiende que el mesmo uso no se pueda por ignorancia corromper. (A. de Nebrija, Gramática de la lengua castellana, edic. A. Quilis ( Madrid, Editora Nacional, 1980) pág. 105)

ARTE de gramatica se llama la que trata, i enseña los prezetos i rreglas para entender, $i$ hablar una lengua. G. Correas: Arte Kastellana, edic. M. Taboada (Universidad de Santiago de Compostela, 1984) pág. 111)

La Gramática es arte que con sus reglas y preceptos enseña a hablar acertado y congruamente. (J. Villar: Arte de la lengua española, Valencia 1651, pág. 1. Cit. en J. M. Lope Blanch: "Actitud de Nebrija ante la lengua castellana", Nebrija cinco siglos después (México, UNAM, 1994) pág. 78.)

El gramático en nuestra tradición asume un doble papel, por un lado dice qué es la lengua; por otro, privilegia ciertos usos y dice lo que la lengua debe ser. Tal forma de entender la gramática como el arte de la corrección en el hablar y escribir se perpetúa durante los

\footnotetext{
${ }^{34}$ Para todas esas documentaciones, confróntese los artículos citados de F. González-Ollé.

${ }^{35}$ Incluso la Gramática de A. Bello responde a este temor: "Sea que yo exagere o no el peligro, él ha sido el principal motivo que me ha inducido a componer esta obra, bajo tantos respectos superior a mis fuerzas. Los lectores inteligentes que me honren leyéndola con alguna atención, verán el cuidado que he puesto en demarcar, por decirlo así, los linderos que respeta el buen uso de nuestra lengua, en medio de la soltura y libertad de sus giros, señalando las corrupciones que más cunden hoy día..." Vid. "Prólogo" de Gramática de la lengua castellana. Destinada al uso de los americanos, edic. R. Trujillo (Madrid, Arco/Libros, 1988) pág. 160.
} 
siglos, de modo que en una de las mejores gramáticas de la lengua española por su finura en el análisis de los hechos lingüísticos, la de A. Bello, se sigue insistiendo en ello, pues es una gramática concebida pensando en el uso que de ella hagan los hablantes americanos: "La gramática de una lengua es el arte de hablarla correctamente, esto es, conforme al buen uso, que es el de la gente educada" ${ }^{36}$. Y esta fórmula sigue repitiéndose en las diversas ediciones de la Gramática de la Academia: "Gramática es el arte de hablar y escribir correctamente. Propónese, por tanto, enseñar a conocer el valor y oficio de las palabras, el modo de formar con ellas oraciones y el de pronunciarlas y escribirlas" ${ }^{37}$, hasta llegar al Esbozo de una nueva gramática de la lengua española, que omite toda definición de Gramática ${ }^{38}$, señala en una advertencia preliminar que la obra carece de todo valor normativo, pero el motivo no radica en un cambio de orientación científica por la presión de las teorías lingüísticas en boga, sino en que la obra es un simple proyecto cuyo contenido estaba todavía en fase de revisión por el grueso de la Corporación ${ }^{39}$. No obstante, uno de los redactores del Esbozo, S. Fernández Ramírez, se planteaba la necesidad de conciliar las aportaciones de la teoría lingüística y la prescripción gramatical:

Para nadie es desconocido que, aun estando dotadas las nuevas investigaciones de un marcado carácter especulativo y té́rico, han ido poco a poco encontrando aplicación, más o menos correctamente entendidas, en determinadas actividades lingüísticas de orden práctico. Por eso no ha dejado de desvelarnos alguna vez el pensamiento de si podría tener análogamente cabida en nuestro texto. La Gramática de la Academia no ha aspirado nunca al conocimiento linguístico puro. Ha sido concebida con miras a un fin utilitario inmediato: es una Gramática normativa (...) Los conceptos de gramaticalidad y competencia, a la orden del día en la investigación, apenas tienen que ver con la norma [prescriptiva]. Como consecuencia de ello [la de la Gramática de la Academia] es literaria, está basada en Autoridades del pasado y del presente, la negación de lo cual constituye un dogma, sine qua non, en la ciencia y en sus aplicaciones didácticas. ${ }^{40}$

\footnotetext{
${ }^{36}$ Vid. "Nociones preliminares", op. cit., pág. 165.

${ }^{37}$ R.A.E.: Gramática de la lengua española ("Introducción") (Madrid, Espasa-Calpe, 1931) pág. 7. En la Gramática de 1771 se dice en el capítulo I: "La gramática es el arte de hablar bien", pág. 119, Gramática de la lengua castellana, edición de R. Sarmiento (Madrid, Editora Nacional, 1984).

${ }^{38}$ Es posible que una definición de Gramática estuviera pensada para la "Introducción"que debía figurar al comienzo de la obra tal y como había previsto S. Fernández Ramírez, pero el Esbozo salió sin ella y también sin la tradicional definición de Gramática que había ilustrado otros Prólogos anteriores.
}

39 "POR SU CARÁCTER, PUES, DE SIMPLE PROYECTO, EL PRESENTE Esbozo CARECE DE TODA VALIDEZ NORMATIVA.", Op. cit., pág. 5.

40 S. Fernández Ramírez: La nueva Gramática de la Academia, edic. de J. Polo (Madrid, Arco/Libros, 1986) pág. 24. Esta preocupación no era exclusiva de Fernández Ramírez; sin embargo, para la mayoría de los filólogos y gramáticos de la Academia, la necesidad de renovar la doctrina gramatical a la luz de las aportaciones de las nuevas corrientes lingüísticas se veía más perentoria que modificar reglas y normas de uso. Así lo manifestaba $\mathrm{R}$. Lapesa en el II Congreso de Academias de la Lengua Española, celebrado en mayo de 1956: "La Real Academia Española reconoce la urgente necesidad de modificar a fondo la Gramática, pero mucho más que en los usos recomendados, en la interpretación teórica de ellos, teniendo en cuenta las concepciones que acerca del lenguaje, sus funciones e instrumentos están hoy vigentes en la lingüística". De ahí que el Esbozo sea una obra en la que se 
Las ideas fatalistas de nuestros gramáticos tradicionales acerca de la inevitable y perturbadora evolución de la lengua debieron determinar la actitud de ciertos hablantes más o menos eruditos que, guiados por un criterio geográfico, situaron ese ideal de lengua en Castilla (algunas de cuyas consecuencias todavía están presentes, aunque sea de forma tenue, en los hablantes de español ${ }^{41}$, más que en los lingüistas). Por tanto, en la edad moderna yà no es Toledo sino Castilla la Vieja el paradigma del buen hablar, dado que la política centralizadora de Felipe V y las tendencias eruditas de la época hacen "del solar del idioma su árbitro" ${ }^{42}$. La idea imperante es que la pureza de la lengua está estrechamente vinculada a su lugar de nacimiento, pues se piensa que al esparcirse por otros dominios se va "contaminando" con elementos extraños que la llenan de impurezas y acentúan su diversificación, con lo que se pone en peligro la unidad del idioma. De hecho, como señala A. Alonso, la relativa unidad lingüística que presidía en los siglos anteriores el habla de la gente culta, en el siglo XVIII aparecía ya fragmentada dialectalmente. Y lo mismo que otras lenguas europeas tienen como canon de ejemplaridad los usos nacidos en París y la Isla de Francia, Florencia o Londres, en España el canon de pureza idiomática se desplazó de Toledo a Castilla la Vieja, algo que influyó, incluso, en la denominación de la lengua (en la alternancia de castellano o español, se hace más estable el nombre de castellano ${ }^{43}$. No obstante, en la preferencia por uno u otro nombre se interfieren según las épocas y los hablantes otras actitudes políticas, culturales y anímicas ${ }^{44}$ ).

La creación de la Academia Española en 1713 a imagen de la Académie Française (1634) y de la Accademia della Crusca (1580) es síntoma de que en la mente del rey Borbón convivía junto al centralismo político y administrativo también un centralismo lingüístico: que todos los hablantes del reino tengan un único referente de lengua común, para lo

mezclan cuestiones teóricas y cuestiones normativas, esto es, está a caballo entre lo que los antiguos llamaban una "gramática disertada" y una "gramática práctica".

${ }^{41}$ Por ejemplo la identificación de la lengua española con un estándar único más próximo a la lengua escrita que a la oral y por ello identificado con la pronunciación castellana, o el prejuicio con que suelen concebir lo dialectal como "un hablar mal" la lengua, depositando la idea de corrección en la pronunciación castellana, etc.

${ }^{42}$ Cfr. A. Alonso: Castellano...

43 "La idea de lo propio e impropio en nuestra lengua, el anhelo de unidad lingüística, la identificación del solar originario con la región actual que más firmemente se mantiene a las leyes del idioma, la atención a regiones que hacen buen uso y a regiones que hacen mal uso de él y a la desigual aproximación de la lengua oral a la literaria en las distintas zonas hispánicas, en suma, las ideas dominantes de propiedad y casticismo, defensa contra las amenazas de fraccionamiento y contra la merma de calidad en la lengua son los impulsos primordiales que se manifiestan en la preferencia de estos espíritus selectos por el nombre de casiellano" (A. Alonso: Castellano...pág. 115).

44 "El uso de uno u otro nombre tiene, pues, justificaciones diversas y ocasionales. En el terreno empírico, aluden a diversas circunstancias y peripecias histórico-culturales de los individuos o de las comunidades que prefieran uno u otro término; en el terreno teórico-lingüístico, la alternancia castellano y español responde a la idea filosófica de que los nombres que damos a las cosas nada dicen de qué sean las cosas en sí y por sí, sino qué son para los hablantes que así las nombran (...) Por consiguiente no es atinado decir que la lengua se llame "más propiamente" con uno o con otro nombre. Pues si la propiedad es la adecuación de la forma exterior al sentido que se quiere expresar, cada uno de los dos nombres designa con igual caacidad el mismo objeto, y cada uno por su lado es más propio para expresar la diferente visión afectiva y valorativa que se haya tenido o se tenga del idioma". Castellano..., pág. 143. 
cual se hace necesario garantizar la pureza de un idioma que se extiende por los confines del mundo. Un hecho que casaba perfectamente con las ideas imperantes de la época de purismo casticista del idioma ${ }^{45}$. Esta actitud se perpetúa con Carlos III, pues a su Real Cédula de 1768 en la que se exigía impartir las enseñanzas primaria y secundaria en el idioma general (pues estaba firmemente convencido de que no se podía estudiar la lengua latina sin conocer suficientemente el idioma nativo -que para él no era sino la lengua general del Estado-), le sigue otra disposición complementaria de 1780: "en todas las escuelas del Reino se enseñe a los niños su lengua nativa por la gramática que ha compuesto y publicado la Real Academia de la Lengua" ${ }^{46}$, la cual, por las razones anteriormente dichas, se quiso atener a un uso castellano del español, pero extraído del manejo que de la lengua hicieron los buenos escritores de los siglos XVI y XVII (es decir, criterio geográfico, sí, pero también, y sobre todo, criterio de autoridad).

Por otra parte, no hay que olvidar que la independencia de las naciones americanas a comienzos del siglo XIX supuso una fragmentación de la unidad de la corona española en una multitud de estados mayores y menores que no sólo tuvo consecuencias políticas inmediatas, sino que afectó también a las actitudes lingüísticas de los nuevos países america$\operatorname{nos}^{47}$. Si hasta entonces la concepción del idioma había sido monocéntrica, en especial por las consecuencias de las actitudes borbónicas en el siglo $\mathrm{XVIII}^{48}$, tras la independencia, las nuevas repúblicas se concibieron como estados nacionales según el modelo europeo y pensaron en definirse en oposición tanto respecto de España como respecto de los vecinos inmediatos. Y así, "junto a la administración, la escuela y el ejército propio pertenece a las instancias de identificación del Estado nacional también la lengua propia. Entonces hablar la lengua de la antigua potencia colonial pudo sentirse como un déficit de emancipación, lo que llevó al intento de seguir conscientemente caminos particulares" ${ }^{49}$ (el ejemplo de Domingo Faustino Sarmiento en Argentina, puede ser buen exponente de esta tendencia) ${ }^{50}$.

\footnotetext{
45 "Estas ideas dieciochescas, íntimamente relacionadas con el ideal de otras formas de la convivencia, eran principalmente el centralismo uniformador, con su corte castellana; el empeño casticista que pone su última instancia en el origen castellano de la lengua, y el propósito purista que, para detener la corrupción disgregadora, apela a la referencia más precisa y más segura de Castilla”. Cfr. A. Alonso: Castellano..., pág. 100.

${ }^{46}$ Cfr. R. Eberenz: "Lengua y legislación" Lexikon der Romanistischen Linguistik, VI, 1 (Tübingen, Max Niemeyer Verlag, 1992) págs. 368-378.

${ }^{47}$ En relación con este tema, puede consultarse el trabajo de G. Guitarte: "Del español de España al español de veinte naciones: La integración de América al concepto de lengua española”, en ACIEA 3, 1 (1991) págs. 65-86.

${ }^{48}$ Reflejadas en la conocida frase de Puigblanch: "Los españoles americanos si dan todo el valor que dar se debe a la uniformidad del lenguaje en ambos hemisferios, han de hacer el sacrificio de atenerse, como a centro de unidad, al de Castilla, que le dio el ser y el nombre". Cfr. A. Rosenblat: "El español de España y el español de América: unidad y diferenciación" en Estudios..., pág. 236.

${ }^{49}$ Cfr. R. Eberenz: "Norm und regionale Standards des Spanishen in Europa und Amerika" en Sprachnormen und Sprachnormenwandel in gegenwärtingen europäishen Sprachen, Universität Rostock, "Rostocker Beiträge zur Sprachwinssenschaft" 1 (1995), 47-58, pág. 48.

${ }^{50}$ Esto, según parece, es la causa, tantas veces denunciada por J. M. Lope Blanch, de que no exista en la actualidad en Hispanoamérica, pese a tener un potencial de hablantes muy superior al peninsular, una norma lingüística
} 
Estas tendencias lingüísticas disgregadoras, que implicaban una consciente hostilidad hacia España, y las continuas guerras entre naciones vecinas (Chile contra Perú y Bolivia o entre Chile y Argentina) supusieron una alarma para muchos eruditos de uno y otro lado del Atlántico, temerosos de que se cumpliera para el español la misma fragmentación que se había dado en el latín ${ }^{51}$. Y así como Clarín había pretendido que "los españoles somos los amos de la lengua" ${ }^{52}$, el colombiano R. J. Cuervo proponía en sus Apuntaciones críticas al habla bogotana un monocentrismo lingüístico de base castellana como medio de evitar la tan temida fragmentación:

¿Cuál será la norma a que todos hayamos de sujetarnos? Ya que la razón no lo pidiera, la necesidad nos forzaría a tomar por dechado de nuestra lengua a la de Castilla, donde nació, y, llevando su nombre, creció y se ilustró con el cultivo de eminentísimos escritores, envidia de las naciones extrañas y encanto de todo el mundo; tipo único reconocido entre los pueblos civilizados, a que debe atenerse quien desee ser entendido y estimado entre ellos ${ }^{53}$.

Pero de ningún modo tal concepción suponía acatar que la posesión de la lengua estuviera en las bocas y en las plumas de los españoles: "Cuando los españoles conservan el fielmente el tipo tradicional, su autoridad es la razón misma; cuando los americanos lo conservamos y los españoles se apartan de él, bien podemos llamarlos al orden y no mudar nuestros usos. Si el beneficio es común, común ha de ser el esfuerzo".

También era temeroso de lo que el futuro pudiera deparar a nuestra lengua A. Bello, de ahí su Gramática "destinada al uso de los hablantes americanos", en cuyo Prólogo alerta

común a todos los países con capacidad de superar en prestigio al estándar de España. Según Lope Blanch, cuando la situación comunicativa requiere acogerse a un ideal de lengua común, ningún hablante hispanoamericano sería capaz de renunciar a sus hábitos linguísticos para adoptar el de una de las naciones hermanas, pues cada una de ellas cuenta con un foco prestigioso de irradiación lingüística que determina la preferencia de los hablantes hacia su modalidad. En esos casos, antes prefieren acogerse a la norma peninsular. En cambio, en aquellos hábitos en los que hay relativo consenso, seseo, yeísmo, distinción etimológica de los pronombres átonos de tercera persona, empleo de las formas de segunda persona ustedes / vosotros, y algún rasgo más, la norma panhispanoamericana se prefiere siempre, aun a costa de los usos prestigiosos de la península. Cfr. varios de sus artículos: "El concepto de prestigio y la norma lingüística del español", Estudios de lingüística española (México, UNAM, 1986) págs. 17. 31; "El ideal de lengua y los países hispanohablantes", Actas del I Congreso Anglo-Hispano I (Madrid, Castalia, 1993) págs. 257-273; "El problema de la lengua española en América" NRFH XLIII, 1 (1995) págs.17-36.

${ }^{51}$ Pesaba todavía la idea de fatalidad en la evolución de las lenguas, debida a las concepciones naturalistas de Schleicher que veían las lenguas tal si fueran organismos vivos

52 Idea que seguía subsistiendo todavía en algunos académicos de principios del siglo XX. Son famosas las palabras de Cotarelo y Mori en las que se defiende la tutela de España y particularmente Castilla en el idioma: "Unidad que debe ser formulada por España, no porque nosotros hablemos actualmente mejor que los americanos, sino porque en España está el tesoro, la mina, la cantera que conserva para el idioma los elementos primarios de firmeza indestructible (...); en España está nuestra vastísima y antigua literatura; a España pertenecen Cervantes y Lope (...); en España está el pueblo castellano, que retiene en sus viejas aldeas voces y giros anteriores al descubrimiento de América. Y ¿qué mejor abolengo pueden desear los que al fin y al cabo, son nuestro hijos?" Citado por D. Fries: La Real Academia ante el uso de la lengua (1713-1973) (Madrid, SGEL, 1989) pág. 171. Nada más lejos hoy de la concepción académica sobre la unidad del idioma, postulada en el principio: "que nuestros clásicos sean también los suyos, y sus clásicos sean también nuestros", formulado en varias ocasiones por R. Lapesa.

${ }^{53}$ R. J. Cuervo: Apuntaciones críticas sobre el lenguaje bogotano, en Obras completas, Bogotá, Instituto Caro y Cuervo, 1954, pág. 6. 
sobre la posibilidad de que los distintos hábitos contaminados por estructuras foráneas conviertan el idioma en "una multitud de dialectos irregulares, licenciosos y bárbaros; embriones de idiomas futuros, que durante una larga elaboración reproducirían en América lo que fue la Europa en el tenebroso período de la corrupción del latín. Chile, Perú, Buenos Aires, Méjico, hablarían cada uno su lengua, o por mejor decir, varias lenguas, como sucede en España, Italia y Francia" ${ }^{54}$. Sin embargo, nada más lejos también de las ideas lingüísticas de Bello que suscribir la frase de Clarín. Las ideas sobre la norma de la lengua no podían ser ya las de un siglo antes, sino otras bien distintas: no hay amos, sino más bien responsabilidad compartida ante el idioma (como años más tarde defendieron $\mathrm{R}$. Menéndez Pidal y D. Alonso):

No se crea que recomendando la conservación del castellano sea mi ánimo tachar de vicioso y espurio todo lo que es peculiar de los americanos: Hay locuciones castizas que en la Península pasan hoy por anticuadas y que subsisten tradicionalmente en Hispanoamérica ¿por qué proscribirlas? Si según la práctica general de los americanos es más analógica la conjugación de algún verbo, ¿por qué razón hemos de preferir la que caprichosamente haya prevalecido en Castilla? Si de raíces castellanas hemos formado vocablos nuevos, según los procederes ordinarios de derivación que el castellano reconoce, y de que se ha servido y se sirve continuamente para aumentar su caudal, ¿qué motivos hay para que nos avergoncemos de usarlos? Chile y Venezuela tienen tanto derecho como Aragón y Andalucía para que se toleren sus accidentales divergencias, cuando las patrocina la costumbre uniforme y auténtica de la gente educada. (A. Bello: Gramática de la lengua castellana, estudio y edición de R. Trujillo (Madrid Arco/Libros, 1988) I, pág. 161)

En efecto, las legítimas aspiraciones de Bello a que se tuvieran en cuenta los usos lingüísticos de los hablantes americanos pueden explicarse porque en la historia de la norma del español, junto al criterio histórico y geográfico, que mira hacia la tradición, hacia Castilla, siempre parece haber convivido, con más peso si cabe, un ideal de lengua sustentado en los usos de los hablantes cultos. Sean estos "los discretos cortesanos" de los que hablaba Cervantes, "la gente culta" 55 "la gente educada"-como escribe A. Bello en el Prólogo-, porque, según él, ella es más permeable a las influencias de la lengua escrita, de la lengua literaria. Es decir, en Bello (lo mismo que en toda nuestra tradición gramatical anterior) se da una especie de simbiosis entre uso y autoridad ${ }^{56}$, que no es más que la pervivencia de algo heredado de la tradición humanística (que, a su vez, hunde sus raíces en la tradición latina, en el doctorum modus loquendi de Varrón y Quintiliano): recuérdese que Gramática era para Nebrija "sciencia de bien hablar y bien escribir cogida del usu y autoridad de los

\footnotetext{
${ }^{54}$ Gramática de la lengua castellana, estudio y edición de R. Trujillo, Madrid Arco/Libros, 1988, I, pág. 160.

55 "Es el bien hablar una de las más claras señales de la gente culta y bien nacida y condición indispensable de cuantos aspiren a utilizar en pro de sus semejantes, ora sea hablando, ora escribiendo, los talentos con que la naturaleza los ha favorecido" (R. J. Cuervo: "Apuntaciones críticas...", pág. 5, en Obras Completas.

56 "Parecerá algunas veces que se han acumulado profusamente los ejemplos; pero sólo se ha hecho cuando se trataba de oponer la práctica de escritores acreditados a novedades viciosas, o de discutir puntos controvertidos, 0 de explicar ciertos procederes de la lengua a que creía no haberse prestado atención hasta ahora", Gramática..., pág. 158-159.
} 
muy enseñados varones" ${ }^{57}$. Y qué autoridad mejor que la literaria, como propugnaban en el siglo XVI algunos autores. Por ejemplo, Fray Luis de León, para quien el bien hablar "no es común, sino negocio de particular juicio, ansi en lo que se dice como en la manera como se dice"; o F. de Herrera, quien en su Controversia con el Prete Jacopín proclama que el privilegio del buen decir está en los poetas y escritores aunque jamás se "hayan asomado a la corte $^{\not 58}$, pues en el fondo, Herrera estaba persuadido de que la lengua oral en sus formas más cultas está alimentada por la lengua literaria; o F. López de Villalobos, para quien "mas deben considerar que en todas las naciones del mundo la habla del arte es la mejor de todas ${ }^{59}$.

Esta concepción estimativa de la norma de la lengua española continúa ininterrumpidamente y se proyecta a todo el siglo XVIII, así que, junto a las tendencias eruditas que sitúan el ideal de lengua en Castilla la Vieja, convive, al menos entre los que tienen en su mano el futuro de la lengua española, un ideal de lengua culta modelada a imagen y semejanza de la de los buenos escritores, como escribió G. Mayans en El orador cristiano, "la pureza del lenguaje es lo que solemos llamar buen romance; esto es, la habla castellana sin vicio alguno. Lo que se dice, pues, debe ser conforme no sólo a los preceptos de la gramática..., sino también al uso de los que hablan bien y de los mejores escritores" ${ }^{\prime 60}$.

Pero el problema de este siglo es que apenas existe un ideal literario acorde con los tiempos, debido al caos y al agostamiento lingüístico y literario que supuso el final del Barroco $^{61}$ : se tiene conciencia de que la lengua poética está exhausta, consumida, por lo que se hace necesario luchar contra esos hábitos desorbitados de torsión de la lengua, destruirlos y construir un ideal nuevo. Para ello se mira con recelo y admiración a la vecina Francia. Con admiración, porque sus letras viven la edad dorada y los franceses sienten la necesidad de fijar la lengua en ese momento culminante; con recelo, porque se observa la pujanza del francés como lengua de cultura europea, cuyos efectos en España se dejan sentir muy pronto en forma de "furor galicista".

La fundación de la Academia Española en 1713 es un intento de regeneración de esa situación actual y de salvación del tesoro lingüístico acumulado en más de siglo y medio de esplendor. El acta primera de la corporación académica muestra como prioritarias las siguientes actuaciones: corregir lo viciado y corrupto, pulir la lengua de voces bárbaras (en

\footnotetext{
${ }^{57}$ Cfr. F. Rico: "De Nebrija a la Academia", Homenaje a Pedro Sainz Rodríguez. Tomo II: Estudios de lengua y literatura, Fundación Universitaria Española, Madrid, 1986, págs. 519-525, pág. 521.

58 "Pero bien debeis saber que la menos buena lengua es la más mezclada, y por eso la cortesana es menos propia, más adulterada, como aquella que sufre más alteración por la diversidad de gentes extrañas que concurren en la Corte", cfr. A. Alonso: Castellano..., pág. 65 , nota 1.

${ }^{59}$ Cfr. R. Menéndez Pidal: La lengua de Cristóbal Colón, pág. 52.

${ }^{60}$ Cfr. F. Lázaro Carreter: Las ideas linguísticas en España durante el siglo XVIII, Barcelona, ed. Crítica, 1985, pág. 260.

${ }^{61}$ Cfr. para todo lo relativo a las ideas linguísticas de este fecundo siglo la obra anteriormente citada de, F. Lázaro Carreter: Las ideas lingüísticas en España durante el siglo XVIII, en especial las partes segunda y tercera.
} 
especial de las tendencias latinizantes de las postrimerías del Barroco) y fijar los usos de lo que se entiende como ideal de lengua, cuyo modelo no es otro que el período cumbre de la literatura, el Siglo de Oro. Es decir, también para la Academia, como para Nebrija, uso y autoridad es lo mismo (aunque para uno y otra el referente no sea el mismo: para Nebrija la autoridad sobre una lengua viva estaba en los humanistas como él, para la Academia parece estar en la lengua literaria). De ahí la lista de autores clásicos (semejante a los cuatrocientos nombres que Nebrija se proponía citar en su nonnata Obra de vocablos):

El poner estas autoridades pareció necessario, porque deseando limpiar, purificar y fijar la lengua, es obligación precisa que la Academia califique la voz, y manifieste los méritos de su juício: pues con este méthodo muestra la moderación con que procéde, y desvanece las inventadas objecciones de querer constituírse maestra de la lengua: porque calificada la voz por límpia, pura, castiza y Española, por medio de su etymología, y autoridades de los escritores; y al contrario, castigada por antiquada, ò por jocósa, inventada, ò usada solo en estilo libre, y no serio: viene à salir al público, con notoriedád de hecho, que la Academia no es maestra, ni maestros los Académicos, sino unos Jueces, que con su estudio han juzgado las voces: y para que no sea libre la sentencia, se añaden los méritos de la causa, propuestos en las autoridades que se $\operatorname{citan}^{62}$

Sin embargo, no todos los eruditos de la época compartían los ideales de la Academia, expuestos claramente en el prólogo y en las páginas precedentes al cuerpo del Diccionario de 1726. Unos, como Feijoo, "porque es cerrar la puerta a muchas voces cuyo uso puede convenir" y "apenas hay escritor de pluma algo suelta que se proponga contenerla dentro de los términos del diccionario" ${ }^{63}$, y porque, además, defendía la penetración de galicismos, aunque no indiscriminadamente, sino sólo cuando son "vozes facultativas cuyo empréstito es indispensable de unas Naciones a otras" ${ }^{64}$. Otros tornaron el casticismo regenerador de la Academia, asentado en los usos clásicos de los buenos escritores, por un ideal racional de claridad, perspicuidad y expresión inequívoca, que desterró toda afectividad del lenguaje y que estaba, por tanto, reñido con el adorno de la frase propio de la expresión poética, razón por la cual muchos eruditos rechazaron toda la creación literaria del siglo XVII. Además, a la sombra de ese estilo racional surgió un purismo estrecho ${ }^{65}$ que reaccionaba contra toda penetración de voces francesas.

En ese intento regenerador que se propone la Academia es labor prioritaria la composición de un diccionario y también la redacción de una Gramática "que reduzca a arte" el

\footnotetext{
${ }^{62}$ RAE: Diccionario de Autoridades, edición facsímil, A-C, Madrid, Gredos, 1984, pág. XIX. La lista de los autores elegidos, "copiosa lista que tiene formada la Académia, sentída de no poder nombrarlos à todos, porque entonces sería Bibliotheca, lo que solo es Catálogo" (pág. XI), principia por el Fuero Juzgo y termina con Luis Vélez de Guevara (págs. LXXXV-LXXXX).

${ }^{63}$ Cfr. Cartas eruditas, I:, citado por F. Lázaro, Las ideas..., pág. 221.

${ }^{64}$ Citado por R. Lapesa: "Sobre el problema de la lengua en Feijoo", El español moderno y contemporáneo, Barcelona, ed. Crítica, 1996, págs. 43-54, pág. 44.

${ }^{65}$ Que, según Lázaro Carreter, poco tiene que ver con el movimiento casticista y anticultista de principios de siglo. Es más bien la cara negativa del casticismo que se caracteriza por ser un muro de oposición a lo neológico y extranjero, en vez de arbitrar fórmulas por las que debe discurrir el lenguaje. Cfr. Las ideas..., págs. 257 y ss.
} 
buen uso de la lengua española. Sin embargo, la magna empresa acometida en la elaboración del Diccionario de Autoridades, cuyo primer tomo se publicó en 1726, y la necesidad de fijar la ortografía, amén de otras causas, motivaron que la primera Gramática de la lengua castellana de esta Institución no se publicara hasta 1771. Es probable que hubiera ciertas reticencias acerca de la necesidad de componer la Gramática de una lengua materna para uso de sus hablantes, pues en el "Prólogo" se justifica su pertinencia mediante una serie de argumentos que se aducen para probar su utilidad ${ }^{66}$, y que concluyen con la conveniencia de una Gramática para todos, apoyando ambas cualidades, utilidad y conveniencia, en sendos argumentos de autoridad ${ }^{67}$ : "No lo pensaban así los Griegos ni los Romanos, pues sin embargo de que para ellos eran tan comunes la lengua griega y latina como para nosotros la castellana, tenian Gramáticas y escuelas para estudiarlas"; "Conocian la utilidad y necesidad del uso; pero conocian tambien que convenia perfeccionarle con el arte"; "Quintiliano dice que es necesaria á los niños, agradable á los viejos, dulce compañera en la soledad, y entre todos los estudios el que tiene mas trabajo que lucimiento" ${ }^{\text {"68 }}$.

Es evidente que en la mente de los académicos de la época aparece como prioritaria la fijación del buen uso, porque sólo en este uso puede fundamentarse el gramático al componer una Gramática que aspira a tener una utilidad práctica: que el usuario discierna entre "lo que debe seguirse y lo que debe excusarse", como se deduce del "Proyecto de Gramática de 1731", obra de Antonio de Angulo:

El uso de las lenguas es indisputablem ${ }^{\text {te }}$ el dueño, y arbitro de ellas, como consta del testimonio de Horacio, y de otro mas autorizado que es la experiencia y observacion de la variedad, y alteracion que hanpadecido todas, y entre ellas la Castellana, de la qual muchas vozes antiguas son hoy de tan dificultosa inteligencia, como si fueran del idioma mas extraño. Este uso tiene gran juego en la Gram. ${ }^{\text {ca }}$, por que siendo el oficio de ella enseñar la lenguas suponiendolas introducidas, y formadas, nace de aqui que el uso es tan poderoso en ellas, es una de las cosas de la maior importancia, y estudio de qualquiera gram. ${ }^{\text {ca }}$ para poder establecer que vozes, phrases y locuciones se deben seguir y quales excusar. En confirmacion de esto Seneca en la Epístola 95 dice, que los Gramaticos son guardas, y no autores del len-

\footnotetext{
${ }^{66}$ Cfr. El estudio de D. Fries: La Real Academia Española ante el uso de la lengua (1713-1973), Op. cit., especialmente el capítulo 3 .

${ }^{67}$ Se aducen también en el "Prólogo" otras razones argumentales, unas de carácter primario (comprobar el uso habitual y corregir los defectos que nacen de la ignorancia): "Si algunas veces vemos comprobada con principios y fundamentos la práctica que teníamos por mera costumbre: otras vemos corregidos muchos defectos que no conocíamos. Ella nos hace ver el maravilloso artificio de la lengua, enseñándonos de qué partes consta, sus nombres, definiciones, y oficios, y como se juntan y enlazan para formar el texido de la oracion. Sobre ninguna de estas cosas se hace reflexîon ántes de entender el arte, y así es difícil que sin él hablemos con propiedad y exactitud, y pureza", otras de carácter secundario, que vienen a reforzar el argumento anterior: "Los que hubieren de emprender la carrera literaria necesitan saber de la lengua latina, y lo conseguirian con mayor facilidad llevando ya sabidos por su Gramática propia los principios que son comunes a todas las lenguas. Los que no hubiesen de seguir la carrera de las letras se ilustrarían á lo menos en esta parte [corrección y propiedad] de ellas, y hallarian en el exercicio de sus empleos, en el gobierno de sus haciendas, y en el trato civil, las ventajas que tienen sobre otros los que se explican correctamente de palabra y por escrito"; concluyendo con la conveniencia de que padres y maestros "instruyesen con tiempo á los niños en la Gramática de su lengua".
}

${ }^{68}$ Gramática... págs. I-II. 
guaje latino, aque lo contrae. Por esto es indispensable en la naturaleza de este Proyecto tratar del uso, pero como se que es asunto que ha tomado un individuo de V.E. para una eruditisima disertacion que esta trabajando y ha de leerse en esta Junta, he creído debo reservarle toda la gloria de este trabajo, y del acierto, a que nunca pudiera yo aspirar, por lo que solo diré, que el uso de que hablamos, es el modo de hablar usado ô mas usado en una nación; pero como en cada Lengua hay bueno y mal uso, es de advertir que en las Lenguas muertas se debe seguir el de los mejores Autores, que hayan escrito en cada una, y esta ha de ser la regla. En las lenguas vivas se debe tomar el uso del que actualm. ${ }^{\text {te }}$ sigue la maior parte de las personas de la Corte, y los mejores escritores del tiempo prn. ${ }^{\text {te }}$, ô de aquel en que no ha padecido alteración la Lengua, y es este uso constante. Otro hay que se llama vario, ô repartido, por que entre la misma especie de gentes, y Autores, se halla seguido por unos, y no por otros, sin poderse distinguir la diferencia y verificar el uso constante en cuio caso queda la livertad de seguir qualquiera de los dos, por que no hay razon que lo contradiga... ${ }^{69}$

Y también de las opiniones de I. Luzán:

El uso que ha de ser el principal norte de la Syntaxis de nuestra lengua, entiendo que debe ser el uso bueno, o como dixo Quintiliano, el consentimiento de los buenos y eruditos, y especialmente el uso actual, alo menos el que han seguido los buenos eruditos, de un siglo a esta parte, o algo mas pues es conforme a razón que ya que se publique ahora una gramática de la lengua, esta sea de la lengua española que hoy se habla. ${ }^{70}$

Como se ve, de todos los usos posibles la autoridad sobre la lengua la determinan los "varones doctos". No cabe duda de que en la primera obra académica, el Diccionario, la autoridad sobre el uso está, como ya se ha dicho, determinada por la lengua literaria. Sin embargo, en el cuerpo doctrinal de la Gramática el uso no parece extraerse de la lengua literaria, sino que más bien descansa, como en Nebrija, en la reflexión que de la lengua y su uso hace el gramático. Esto es, al menos, lo que puede desprenderse de una Gramática en la que prácticamente no hay citas de autoridad ${ }^{71}$. En cambio, las reformas que se hicieron en el siglo XIX sí hacen pensar que se acentuó más el ideal de lengua basado en la lengua literaria, pues fueron aumentando progresivamente el número de estos ejemplos (algunas llegaron a publicar un listado de autoridades), hasta llegar a la Gramática de 1931, de la que ya puede decirse que es un verdadera Gramática de autoridades en la que predominan

${ }^{69} \mathrm{Cfr}$. "Apéndice documental" a la Gramática de la lengua castellana de 1771, ed. de R. Sarmiento, págs.504-505.

${ }^{70}$ Cfr. R. Sarmiento: "Introducción” a la Gramática..., pág. 41.

${ }^{71}$ En efecto, llama la atención del investigador, acostumbrado a las Gramáticas más modernas de la Academia, plagadas de ejemplos literarios en los que no siempre se disciernen los autores más antiguos de los más modernos, que la Gramática de 1771 use las autoridades literarias sobre todo para condenar usos anticuados, impropios ya del uso culto o para documentar una evolución histórica (así, Las Partidas, El Fuero Juzgo, la Primera Crónica General y Hernando del Pulgar proporcionan ejemplos para documentar las formas del futuro analítico o la alternancia de las terminaciones verbales -ía /-ie o la concordancia del participio con el OD en la perífrasis ovo + participio [ovo contados los averes], y el valor 'había cantado' de cantara). Sólo en el capítulo dedicado a la sintaxis figurada, los gramáticos acuden a ejemplos de Saavedra Fajardo para hablar del orden de palabras y de la elipsis. Es posible ver aquí cierto paralelismo con la actitud de Nebrija en su Gramática, que sólo acude a ejemplos literarios al hablar de métrica o de retórica, pero no en el cuerpo doctrinal de la gramática, a no ser para sancionar un uso como inadecuado. Cfr. E. de Bustos Tovar: "Nebrija, primer lingüista español", Nebrija y la introducción de Renacimiento en España (Salamanca, 1983) pág. 206-222. 
los textos del Siglo de Oro (y, aunque algunos de ellos se emplean para documentar arcaísmos, la mayor parte se usa para documentar usos contemporáneos), siguen los del XIX y, a mayor distancia, los del XVIII ${ }^{72}$. La publicación en 1973 del Esbozo de una nueva gramática de la lengua española, supone ya una renovación en la selección de los modelos literarios y aunque no excluye ejemplos del Siglo de Oro, éstos constituyen sólo una pequeña proporción del corpus utilizado. Hay, además, una nutrida representación de autores del presente siglo y lo más importante: por primera vez se tienen en cuenta como modelo en la descripción del uso escritores hispanoamericanos, indicio ya de que concepción de la norma se ha hecho más panhispánica. También es novedad la selección de dos publicaciones periódicas: $A b c$ de Madrid y El Mundo de Puerto Rico, que van abriendo camino a la lengua periodística como modelo digno de ser tenido en cuenta en la descripción.

De todo lo dicho hasta aquí, se desprende que para la Academia el cuidado de la lengua debe orientarse a partir de la lengua escrita tanto por la trascendencia que ésta tiene para el desarrollo del hombre como ser racional ${ }^{73}$, cuanto por la importancia que tiene para el mantenimiento de la unidad lingüística. Esto puede explicarse, en parte, por la creencia, hasta no hace mucho tiempo, de que la lengua escrita es un epifenómeno de lo oral, una especie de transubstanciación, tal y como parece desprenderse de las palabras de S. Fernández Ramírez citadas anteriormente: "Pero no debe perderse de vista que mi objetivo es el español común, el español cuidado que hablan las gentes cultas y universitarias de Madrid. $\mathrm{Y}$ entre ese español hablado y literario no existe, sobre todo en nuestros días, una distancia considerable".

Sin embargo, tal actitud lleva aparejado cierto conservadurismo lingüístico que puede llevar a perder de vista, si no en los lingüistas sí en el resto de los hablantes, que los usos orales de la lengua no siempre tienen por qué estar modelados a imagen y semejanza de los usos escritos, y mucho menos, de los modelos literarios. Pese a todo, tal concepción pudiera ser defendible si atendemos a que las especiales condiciones que concurren en la lengua escrita neutralizan las diferencias internas de la lengua y permiten que actúe como supernorma conformadora de la lengua común. No obstante, no se pueden obviar las consecuencias que ese proceder de nuestra tradición gramatical ha tenido, y tiene hoy todavía, en el hablante medio, ya que lo que se suele llamar uso estándar, es la única variedad de lengua codificada explícitamente en gramáticas y diccionarios, de tal forma que muchos de los hablantes que tienen acceso a ella mediante la enseñanza (hoy también por la acción de los medios de comunicación) creen que es el único modelo de corrección posible que ha de aplicarse por igual a todas las situaciones comunicativas. Es decir, la codificación parece proporcionar a los hablantes comunes una visión monolítica de la lengua que les induce a creer que las variedades dialectales no codificadas son "una forma de hablar mal la lengua" $y$, esto, en casos muy concretos, se puede plasmar en una deslealtad lingüística hacia las variantes de su grupo. Es decir, la selección y codificación de un uso mueve en muchos

\footnotetext{
${ }^{72}$ Cfr. D. Fries: La Real Academia Española..., págs. 166-172.

${ }^{73}$ Cfr. el discurso de entrada de en la Academia de S. Fernández Ramírez: Lengua literaria y norma lingüística, leído el 29 de mayo de 1960.
} 
casos a extremar una actitud purista y muy conservadora del idioma que con frecuencia se plasma, por ejemplo, en las quejas y censuras (la sección de "Cartas al director" de los periódicos es buena muestra de ello) por la presencia de variedades dialectales en los profesionales de los medios de comunicación o por usos sintácticos, morfológicos o léxicos no estrictamente canónicos (si se miran desde lo que está expresamente codificado) y que, sin embargo están totalmente extendidos. Tampoco son infrecuentes las críticas a la Academia por no ser lo suficientemente estricta y claudicar admitiendo dentro del estándar las variables disidentes.

Pero también es posible (y de hecho es bastante frecuente) que las normas de corrección medidas respecto del estándar actúen en sentido inverso y ocasionen reacciones contrarias a cualquier sujeción a un canon normativo concreto; tal postura cuenta hoy con numerosos adeptos, influidos quizá por la actitud antinormativa de la teoría lingüística que ha calado en las nuevas generaciones de profesores y maestros de lengua española. En consecuencia, se reivindican las variedades dialectales para que actúen en situaciones, por lo común, reservadas al estándar y se tiene una actitud de tolerancia hacia cualquier variante lingüística, independientemente de su adscripción social (no pocas veces estas actitudes llevan a reivindicar como dialectalismos lo que no son más que vulgarismos, impropios de un uso culto y desechado por los propios hablantes en situaciones comunicativas formalizadas). Es explicable, por tanto, que desde esta concepción del ideal de lengua y de las normas de corrección se vea a la Academia como una institución obsoleta, ineficaz, conservadora de lo establecido y enemiga de innovaciones, a la que poco caso en materia de uso habría que hacer.

Como puede verse, en el fondo, las actitudes de puristas y tolerantes descansan en la misma concepción errónea de lo que es una lengua codificada, llámese ésta ejemplar, estándar o lengua culta: para ellos es la lengua toda. Por esa razón, en la creencia de que esa lengua existe como un ideal único y sin fisuras, que actúa como un patrón lingüístico aplicable sin excepción a cualquier situación del hablar, los hablantes pueden desdoblarse en sus juicios, manifestando dos actitudes lingüísticas bien diferenciadas: los unos tildan de incorrectos usos dialectales porque creen que no están, o no pueden estar, instalados en el estándar (sin tener en cuenta en qué situación comunicativa se usan, ni con qué modelo de actuación pretende corresponderse), los otros, acusan de deslealtad lingüística al hablante por despojarse de sus hábitos dialectales cuando en una situación comunicativa de trascendencia superior se acoge al modelo estándar o de lengua culta (que, como bien se sabe tampoco es unitario) como guía de su actuación. Parece como si la función del estándar (que, no se olvide, está extraído de la lengua escrita, especialmente de la lengua literaria) como marco de referencia para los hablantes suscitara en ellos prejuicios y tópicos que les impidiera entender la variación diafásica, e interfiriera también en la concepción que se tiene de la variación diatópica.

En este sentido, tampoco hay que olvidar que hasta no hace mucho los hablantes cultos del español se identificaban (en España al menos) sobre todo con una norma culta peninsular más cercana, en lo que a pronunciación se refiere, a la lengua escrita. De hecho, las descripciones de las gramáticas de la Academia tenían, hasta la elaboración del Esbozo, 
como únicos referentes los usos peninsulares norteños. Algo que ha cambiado en la actualidad: hoy los adelantos de la ciencia lingüística han determinado una visión de la lengua como un bien mostrenco en el que nadie, absolutamente nadie tiene completa autoridad sobre ella; de modo que en una comunidad lingüística tan extendida como la nuestra, quien determina qué usos son prestigiosos (dignos de codificación, por tanto) y qué usos no lo son es la sociedad culta de cada nación que actúa como foco de irradiación de formas prestigiosas. De ahí que para el español no exista un único modelo de ejemplaridad, sino más bien un cierto eclecticismo que tiende a acoger soluciones alternantes y variables según las zonas. Este cambio de actitud ha motivado que muchos hábitos, proscritos antes, encuentren ahora sitio en la descripción por ser prestigiosos en sus comunidades respectivas. Es decir, se ha producido un cambio en la explicitación de la norma del español: de una norma eurocéntrica a una norma policéntrica, más cercana, al fin, a un ideal panhispánico que fortalezca los lazos de unidad lingüística.

Tales actitudes de responsabilidad compartida ante el idioma, no sólo han afectado al español de América en sus relaciones con la norma del español, sino también al de España, sobre todo en lo que respecta al lugar que ocupa el español meridional ${ }^{74}$, no sólo con respecto a la norma, sino con respecto a las virtualidades de sus empleos, que se han visto incrementados y aparecen ya en situaciones comunicativas en las que antes, aparentemente, estaban vedados.

Por todo lo expuesto hasta aquí parece algo evidente lo mucho que se ha adelantado en la codificación de la lengua española: ha cambiado la selección de los usos que pertenecen ya a todo el dominio hispánico, lo que afectará sin duda a la visión normativa de los hablantes y a su tolerancia hacia otros posibles modos de ser la lengua española. Ahora bien, lamentablemente, estos adelantos poco han variado la concepción de ese ideal de lengua, que sigue estando en la lengua escrita (mejor si es literaria). No parece que todavía haya encontrado hueco en la descripción la variación propia de la lengua hablada (y, precisamente, es la que presenta más diversidad) que, como se sabe, no siempre puede analizarse con los parámetros que proporciona una gramática de la lengua escrita. Por esta razón deben extremarse todos los cuidados, pues dada la visión normativa de la codificación que poseen los hablantes, puede ocurrir que se proscriba, teniendo como marco de referencia la lengua escrita, un uso absolutamente habitual y normal en la lengua hablada espontáneamente por las personas cultas de las diversas naciones de habla hișpana.

\footnotetext{
${ }^{74}$ De hecho, algunos reivindicadores del andaluz, especialmente persistentes en la época de la transición política, reclamaban para esta variedad el mismo trato que tenían ya las variedades americanas y el canario, y exigían que en situaciones comunicativas formalizadas (por ejemplo, hablar en los medios de comunicación) no se les obligase a acogerse a una norma de pronunciación norteña, aludiendo a que ciertos hábitos de pronunciación, además de estar muy extendidos, eran prestigiosos dentro de la sociedad culta andaluza.
} 